\title{
Consumption of medicines in high-risk pregnancy: evaluation of determinants related to the use of prescription drugs and self-medication
}

\author{
Danielle Dayse Araújo, ${ }^{1, *}$, Marineide Marinho Leal ${ }^{2}$, Eliane Jucielly Vasconcelos Santos², \\ Leila Bastos Leal ${ }^{3}$
}

\begin{abstract}
${ }^{1}$ Department of Pharmacy, Federal University of Pernambuco, Recife, PE, Brazil, ${ }^{2}$ Clinical Hospital, Federal University of Pernambuco, Recife, PE, Brazil, ${ }^{3}$ Nucleus of Pharmaceutical and Cosmetic Development, Department of Pharmacy, Federal University of Pernambuco, Recife, PE, Brazil
\end{abstract}

\begin{abstract}
The use of drugs during pregnancy still represents a challenge for medicine, since the majority of drugs cross the placental barrier with a potential to cause several congenital problems to the fetus, and most of them have not been clinically tested in pregnant patients. At the same time, the medicalization phenomenon, self-medication, and lack of patient information about the misuse of medicines are additional problems. Thus, the aim of this study was to evaluate the pattern of medicine consumption in high-risk pregnancies and the determinants related to this consumption pattern. In order to do so, a cross-sectional descriptive study was performed with puerperal women who had a history of high-risk pregnancy. Statistically significant associations were found between self-medication and fewer prenatal visits, and cigarette use during pregnancy and a higher number of children. According to these data, the vulnerability of this population to the risks of drug use is evident, demonstrating a gap that requires urgent interventions in health-care education.
\end{abstract}

Uniterms: Medicines/adverse effects. Pregnancy/medicines use. Self-medication. Health education.

O uso de medicamentos na gestação representa, ainda hoje, um desafio para a medicina, visto que grande parte dos fármacos atravessa a barreira placentária e, na maioria, não foi testada clinicamente em gestantes, podendo vir a ocasionar diversos problemas congênitos ao feto. Ao mesmo tempo, a automedicação, o fenômeno da medicalização e a falta de informação sobre os riscos do mau uso de medicamentos são problemas adicionais. Diante disto, o objetivo deste estudo consistiu em avaliar o padrão de consumo de medicamentos na gestação de alto risco e os determinantes relacionados ao seu padrão de consumo. Para tanto, realizou-se um estudo descritivo de corte transversal com puérperas, que apresentaram gestação de alto risco. Verificaram-se associações estatisticamente significativas entre automedicação e mulheres com menor número de consultas de pré-natal, uso de cigarro na gestação e maior número de filhos. De posse destes dados, fica evidente a vulnerabilidade dessa população aos riscos decorrentes do uso de medicamentos, sendo esta lacuna um campo de prática com necessidade de intervenções urgentes no âmbito da educação em saúde.

Unitermos: Medicamentos/efeitos adversos. Gestação/uso de medicametos. Automedicação. Educação em saúde.

\section{INTRODUCTION}

The use of medicines during pregnancy still

\footnotetext{
*Correspondence: D.D. Araújo. Núcleo de Desenvolvimento Farmacêutico e Cosmético (NUDFAC)/Departamento de Farmácia, Universidade Federal de Pernambuco. Av. Prof. Moraes Rego, 1235, Cidade Universitária, 50670-901

- Recife - Pernambuco, Brasil. E-mail: danielledayse@hotmail.com
}

represents a challenge for medicine, since the majority of drugs cross the placental barrier (Della-Giustina, Chow, 2003). Despite knowing the selective permeability of the placenta, human placental transfer is not well known, since the majority of the available information comes from experiences in mammals. This limitation in studies of drugs in pregnant women is due to ethical and safety 
reasons, and when there are data on medicines, they are from case studies in which the use of such medicine is necessary for a better maternal-infant outcome (Cavalli, Baraldi, Cunha, 2006).

It is estimated that $10 \%$ or more of the congenital defects are the result of a previous exposure of the mother to drugs (Nakamura, Junior, Pasquale, 2008). In order to simplify the evaluation of medicines for pregnant women in a practical way, the Food and Drug Administration (FDA) classifies drugs in risk categories:

In Category A, the possibility of fetal risk seems to be remote; in Category B, there is no controlled study in pregnant women, or the studies in animals demonstrating effects to the fetus were not confirmed in pregnant women; in Category $\mathrm{C}$, there are studies in animals that reveal teratogenic effects to the fetus, but there are no available studies about the drug in women, thus these drugs must be used only if the benefits are higher than the potential risk; Category D, there is positive evidence of risk to the human fetus, but the benefits of the use during pregnancy are acceptable despite the risk; lastly, in Category X the drugs are contraindicated due to evidence of fetal abnormalities in animals or humans (Department of Health and Human Services, 2008).

Besides the risk of using certain medicines, modifications in the maternal organism during pregnancy may interfere in the extension of fetal exposure to the drug administrated to the mother. This effect depends on different factors, particularly the mother-fetus elimination mechanism and placenta permeability, in addition to the reduction of plasmatic carrying proteins and increase of cardiac work, which reflects an increased level of glomerular filtration and kidney clearance of the drug (Morgan, 1997).

Despite the risks imposed on the fetus by the utilization of medicines during pregnancy, Carmo (2003) describes the current picture of this practice as the medicalization of pregnant women. Described by Barros (1995), medicalization is a phenomenon seen in contemporary society, which is based on elevated dependence on medical services and subsequent intensive consumption of practices and instruments considered as health. Pregnancy medicalization is even more evident in the high-risk pregnant woman, because of the passivity against something that is possibly adverse, even though it is not the case (Gomes et al., 2001).

Another practice to be considered during pregnancy is self-medication, which carries a double risk, as it may be a risk factor not only to the mother, but to the forming fetus as well. Usually, this is done when the woman is seeking relief for symptoms caused by physiologic changes that occur during this period, when the indiscriminate use of drugs is performed in order to combat nausea, anemia, pain, and nutritional deficiencies, among others (Mengue et al., 2004).

When it comes to high-risk pregnancy, necessary attention to the use of medicines is even higher. It is indispensable to know the aspects related to the consumption of medicines by this group of pregnant women, since they show specific characteristics, or suffer with some grievance, that represents greater probability of unfavorable progression for both fetus and mother.

According to the above, the aim of this work was to evaluate the consumption pattern of medicines during pregnancy, prescription drugs or self-medication, in puerperal women with high-risk pregnancies and the determinants related to their consumption pattern. This study was carried out at the Maternity of Clinical Hospital of the Federal University of Pernambuco (HC/UFPE), a reference service in high-risk pregnancy that serves pregnant women from several cities of the state, besides low-risk pregnant women, admitted during labor.

\section{MATERIAL AND METHODS}

A cross-sectional descriptive study was carried out and the population consisted of puerperal women admitted at Maternity of HC/UFPE, from October to December of 2011. The criteria for inclusion in the study were giving birth in the hospital and the classification of the pregnancy as high-risk according to the criteria presented by Technical Manual: High-Risk Pregnancy of Health Ministry (Brasil, 2010).

The sample used was proportional with a confidence level of $95.0 \%$ and a sampling error of $5 \%$. The expected frequency used for the calculation was $85.0 \%$, a value based on various studies of drug use by pregnant women, either high or low risk (Mengue et al., 2004; Melo et al., 2009; Brum et al., 2011; Guerra et al., 2008). According to data collected at the Center for Epidemiology HC / UFPE, the average number of births in 2010 was 110 births per month, resulting in a population of 330 mothers for the three months of data collection, including both low-risk and high-risk pregnancies. The estimated value of the sample was 123 , plus $10 \%$ for losses, resulting in a total of 136 subjects.

The instrument used for data collection was a structured questionnaire that was formulated by the researcher. The questionnaire was presented in five sections, including questions related to sociodemographic data, access to health care services, health and obstetric history, prescription drug use, and data related to 
self-medication. Prior to data collection, a pilot test was performed in order to confirm the validity of the instrument. The data needed for completing the survey were obtained exclusively through answers from participants, and with secondary data from medical records just to verify that participants fulfilled the inclusion criteria for the study (high-risk pregnancy) and confirmation of the gestational age at birth.

The processing and analysis of data was performed using the statistical package SPSS (Statistical Package for the Social Sciences) version 10.0 for Windows, initially with the construction of the database and with sequential analysis to check for inconsistencies. Next, a categorization of continuous variables was made to allow implementation of the measures of association between exposure and outcome. A description of these categorized variables the population was made through simple frequencies.

The statistical test performed involved bivariate analysis between two categorical variables, measuring the association using an odds ratio (OR), for the identification of an association between the independent variables and the dependent variables (self-medication and more drugs used). A confidence interval of $95 \%$ and alpha of less than 5 were considered statistically significant. The independent variables of the study included: age, origin, race, marital status, number of children, education, family income, number of prenatal visits, gestational age, health service used, smoking cigarettes or drinking alcohol during pregnancy, history of abortion, and knowledge about the risks of drug use during pregnancy.

The research project of this study was approved by the Ethics Research Center of Health Sciences, Federal University of Pernambuco.

\section{RESULTS AND DISCUSSION}

Of the initial sample of 136 subjects, 25 were eliminated by exclusion criteria (mostly for low-risk pregnancies), 33 refused to participate in the study for various reasons, mostly related to limitations in the postpartum period, resulting in a total of 78 study participants.

The population profile of the puerperal women, detailed in Table I, consists mostly of adult women, predominantly Brown or Black, residents mainly from the metropolitan region of Recife, consisting of 14 cities. Most women had a partner, few children, more than 8 years of school education, and family income above the minimum wage.

The analysis of aspects related to health services
TABLE I - Distribution of the sociodemographic variables of puerperal women interned in HC/UFPE after high-risk pregnancy, 2011

\begin{tabular}{|c|c|c|}
\hline Variables & $\mathbf{N}$ & $\%$ \\
\hline \multicolumn{3}{|l|}{ Age (years) } \\
\hline 10 to 19 & 16 & 20.5 \\
\hline$\geq 20$ & 62 & 79.5 \\
\hline \multicolumn{3}{|l|}{ Origin } \\
\hline Metropolitan region & 44 & 56.4 \\
\hline Countryside & 34 & 43.6 \\
\hline \multicolumn{3}{|l|}{ Race } \\
\hline Black/Brown/Indigenous & 59 & 75.6 \\
\hline Caucasian/Asian/Other & 19 & 24.4 \\
\hline \multicolumn{3}{|l|}{ Marital status } \\
\hline With partner & 70 & 89.7 \\
\hline Without partner & 8 & 10.3 \\
\hline \multicolumn{3}{|l|}{ Number of children } \\
\hline 1 to 2 children & 60 & 76.9 \\
\hline$\geq 3$ children & 18 & 23.1 \\
\hline \multicolumn{3}{|l|}{ Education status (years) } \\
\hline$<8$ & 21 & 26.9 \\
\hline$\geq 8$ & 57 & 73.1 \\
\hline \multicolumn{3}{|l|}{ Family income } \\
\hline$\leq$ minimum wage & 31 & 39.5 \\
\hline$>1 \times$ minimum wage & 47 & 60.3 \\
\hline
\end{tabular}

revealed that the entire study population attended at least one prenatal consultation (100\%), with only $2.6 \%$ referring distance from the service to their residence. The number of medical consultations was predominantly above seven $(60.3 \%)$, with almost all patients using public health services for this purpose $(98.7 \%)$.

Although all participants had access to prenatal consultations through SUS (Single Health System), and most had attended more than 6 consults as recommended by the Program for Humanization of Prenatal and Birth instituted by the Ministry of Health (2002), a large proportion of pregnant women, $75.6 \%$, also resorted to private services, especially ultrasound exams.

Regarding obstetric data, the majority of the studied population $(64.1 \%$ ) had a full-term delivery (above 37 weeks of gestation), with $20.5 \%$ of women showing abortion antecedents. Tobacco use during pregnancy was admitted by $12.8 \%$ and alcohol use by $16.7 \%$ of the puerperal women (Table II).

The values found in this study that were related to the use of alcohol and tobacco during pregnancy are higher than found in the research of Freire, Padilha and Sauders (2009), where only $5.5 \%$ of pregnant women reported having smoked and $7.4 \%$ reported having drank, and these practices were related by the authors as strongly associated 
with each other, and more related to women who lived without a partner and were above 35 years of age.

TABLE II - Distribution of the variables related to health issues during gestation in puerperal women interned in HC/UFPE after high-risk pregnancy, 2011

\begin{tabular}{lcc}
\hline Variables & $\mathbf{N}$ & $\mathbf{\%}$ \\
\hline $\begin{array}{l}\text { Gestational age at birth (weeks) } \\
\quad \leq 37 \text { (preterm) }\end{array}$ & 28 & 35.9 \\
$\quad>37$ (term) & 50 & 64.1 \\
$\begin{array}{l}\text { Previous abortion } \\
\quad \text { No }\end{array}$ & 62 & 79.5 \\
$\quad$ Yes & 16 & 20.5 \\
$\quad \begin{array}{l}\text { Smoked during pregnancy } \\
\quad \text { No }\end{array}$ & 68 & 87.2 \\
$\quad$ Yes & 10 & 12.8 \\
$\quad \begin{array}{l}\text { Drank alcohol during pregnancy } \\
\quad \text { No }\end{array}$ & 65 & 83.3 \\
$\quad$ Yes & 13 & 16.7 \\
$\quad \begin{array}{l}\text { Use of medicines during pregnancy } \\
\text { (prescription or self-medication) }\end{array}$ & & \\
$\quad$ No & & \\
$\quad$ Yes & 0 & 0,0 \\
Self-medication & 78 & 100,0 \\
$\quad$ No & & \\
$\quad$ Yes & 56 & 71.8 \\
\hline
\end{tabular}

Regarding drug use, all participants (100\%) used at least one medicine during pregnancy, either a prescription drug or through self-medication, with a mean of 4.6 drugs per participant, and variation from a minimum of 1 to a maximum of 11 drugs. Fontoura (2009) reports a prevalence similar to the one obtained in our study, where $98 \%$ of the pregnant used some kind of medicine during pregnancy. Other authors report a lower prevalence, such as $76.4 \%, 80.1 \%$, and $90 \%$ (Oliveira, Fonseca, 2007; Geib et al., 2007; Brum et al., 2011).

It is important to consider that the use of medicines and the means of medicines used per pregnant woman vary considerably in different studies probably due to different methodologies applied in the respective studies. In the present study, we chose to study the total number of drugs, rather than the number of medicines, used by pregnant women during gestation. Since many medicines show combined formulations containing more than one active drug, this study takes into account the risk of exposure to each drug.

In this manner, we can infer that the mean number of drugs used by the puerperal women in our study is greater than the values found in medical literature as a consequence of these methodological differences, such as the ones observed by Osório de Castro et al. (2004), Guerra et al. (2008); Fonseca, Fonseca, Bergsten-Mendes (2002), and Brum et al. (2011), where they related means of 2.3; 2.4; 3; and 4.1 drugs per pregnant woman, respectively. Therefore, it is not prudent to relate the higher mean to the fact that our patients had high-risk pregnancies.

Regarding the use of prescription drugs by the volunteers, it was possible to obtain a mean of 4.2 drugs per volunteer, where $61.5 \%$ of women consumed from 1 to 4 drugs and $38.5 \%$ used more than 4 drugs during pregnancy. The minimal number of medicines used was one and the maximum was 11 per patient.

Several authors discuss the utilization of medicines during pregnancy as a consequence of a prescriptive practice, using also the concept of medicalization during pregnancy that, according to Barros (1995), contributes to the transformation of normal physiological processes into pathological states, such as in pregnancy and childbirth. In fact, it is convenient to highlight that an irrational prescription of medicines exposes the mother and the fetus to avoidable risks. However, an extremely conservative posture due to fear of embryo/fetus toxicity, in some cases, might lead a woman to unnecessary suffering (Fonseca, Fonseca, Bergsten-Mendes, 2002). Furthermore, some maternal pathologic situations that often result in a high-risk pregnancy should be prioritized and pharmacologically treated, under commitment penalty of pregnancy and/or generate more risks to the mother and to the fetus (Gedeon et al., 2006).

Self-medication during pregnancy was admitted by $28.2 \%$ of patients (Table II), with the quantity varying between 1 to 4 medicines, and a mean of 1.4 among women that engaged in self-medication. This prevalence corroborates the study carried out by Fonseca, Fonseca and Bergsten-Mendes (2002), which was of $31.2 \%$. However, it was considerably inferior to the one found by Brum et al. (2011), where the prevalence of self-medication was $50 \%$ of the studied pregnant women.

The variable related to women's knowledge about the risk of using medicines during pregnancy showed that $11.5 \%$ of patients were unaware of the risk. This result can be compared to the one of Melo et al. (2009), with 205 pregnant women from an antenatal service of the Single Health System (SUS), which observed that $19.5 \%$ of women never received information about the risks of some medicines used during pregnancy. The same authors have done a comparison with the study performed by Oliveira and Fonseca (2007), where 44.4\% of women declared they were not informed about the risk of drugs used during pregnancy. They questioned the need for developing educational programs aimed at the minimization of this 
kind of problem in basic health care services.

The prescription drugs that were used by patients during pregnancy and components of the medicines cited in the study are shown in Table III according to therapeutic class and prevalence of use. The division of the drugs into therapeutic classes followed the classification system of the Anatomical Therapeutic Chemical (ATC), identified by codes. The active substances are divided into different groups according to the organ or system on which they act and their therapeutic, pharmacological, and chemical properties

An important piece of data to be highlighted is that $20.5 \%$ of the women participating in the present study used some medicine they did not know the name of, citing only its purpose. In the study performed by Osório de Castro et al. (2004), 9.3\% of the pregnant women could not identify the medicine or the active ingredient used, reporting in $15.5 \%$ of the cases use "for pain" and in $12.7 \%$ "for urinary infection."

In terms of FDA pregnancy risk category for prescription drugs used by patients, the present study showed that $14.0 \%$ of these drugs belong to risk classification A; $37.2 \%$ belong to the B class; $39.5 \%$ belong to the $\mathrm{C}$ class, and $9.3 \%$ of the drugs belong to risk classification D.

Since our study population consisted only of puerperal women with high-risk pregnancies, including women with previous chronic diseases or who suffered some health intercurrence during pregnancy, the use of D class medicines was expected, as these were drugs in which the benefits of use overcome the potential risks to the fetus. However, the percentage of drugs that belonged to D class was small, when compared to the percentages of $\mathrm{B}$ and $\mathrm{C}$ class drugs used in the study.

According to Geib et al. (2007), the use of class A medicines is associated with prenatal attention, reinforcing the prevention of gestational and fetal damage, since this class contains antianemics and vitamins. Drugs that belong to $\mathrm{B}, \mathrm{C}$, and $\mathrm{D}$ classes have their consumption associated with intercurrences of health in pregnancy, having the $\mathrm{B}$ class a consumption adequacy; the $\mathrm{C}$ class with biological factors related to history of abortion and caesarean; and the $\mathrm{D}$ class lower consumption in the economic classes less favored.

TABLE III - Distribution of prescribed drugs during gestation, according to the Anatomical Therapeutic Chemical Classification System (ATC), used by puerperal women interned in HC / UFPE after high-risk pregnancy, 2011

\begin{tabular}{lccl}
\hline Therapeutic classes (ATC code) & N & $\%$ & Drugs \\
\hline Antianemic preparations (B03) & 75 & 96.2 & \\
$\quad$ Iron Preparations (B03A) & 69 & 88.5 & ferrous sulfate, ferric hydroxide \\
$\quad$ Vitamin B12 and Folic acid (B03B) & 48 & 61.5 & folic acid \\
Vitamins (A11) & 17 & 21.8 & multivitamins, vitamin C, B complex \\
Analgesics (N02) & 45 & 57.7 & dipyrone, paracetamol \\
Corticosteroids for systemic use (H02) & 2 & 2.6 & betamethasone, prednisone \\
Antibacterials for systemic use (J01) & 22 & 28.2 & amoxicillin, ampicillin, benzathine \\
& & & benzylpenicillin, cefalexin, cefuroxime-axetil, \\
& & & ciprofloxacin, norfloxacin \\
Gynecological antiinfectives and antiseptics (G01) & 20 & 25.6 & amphotericin B, clindamycin, metronidazole, \\
& & & miconazole nitrate, nystatin, tetracyclin \\
Antiprotozoals (P01) & 1 & 1.3 & tinidazole \\
Antifungals for dermatological use (D01) & 1 & 1.3 & ketoconazole \\
Antimycotics for systemic use (J02) & 1.3 & fluconazole \\
Drugs for functional gastrointestinal disorders (A03) & 13 & 16.7 & bromopride, butylscopolamine bromide, \\
& & & metoclopramide, \\
Drugs for acid related disorders (A02) & 9 & 11.5 & aluminum hydroxide, omeprazole \\
Antihistamines for systemic use (R06) & 17 & 21.8 & dimenhydrinate, promethazine, \\
& & & dexchlorpheniramine, meclizine \\
Cardiovascular system (C) & 14 & 17.9 & atenolol, enalapril, methyldopa \\
Immunosuppressants (L04) & 1 & 1.3 & azathioprine \\
Antiepileptics (N03) & 1 & 1.3 & lamotrigine \\
Psycholeptics (N05) & 2 & 2.6 & haloperidol \\
Drugs for obstructive airway diseases (R03) & 1 & 1.3 & budesonide \\
Sex hormones and modulators of the genital system (G03) & 2 & 2.6 & progesterone \\
\hline
\end{tabular}


Table IV shows the drugs according to their therapeutic classes and prevalence of use, and components of medicines participants reported consuming through self-medication. Self-medication with analgesics and antipyretics by a considerable portion of the women was comparable to values found by other authors (Fonseca, Fonseca, Bergsten-Mendes, 2002; Brum et al., 2011; Guerra et al., 2008). Among analgesics, paracetamol is considered a safe drug for use in pregnancy and belongs in FDA category B, while dipyrone and aspirin belong to the risk category $\mathrm{C}$.

Self-medication in this study also involved the consumption of anti-inflammatory drugs classified as fetal risk categories $\mathrm{C}$ or $\mathrm{D}$, depending on gestational age. Antiinflammatory, non-steroidal medicines are commonly used by pregnant women for painful conditions including back pain, urinary tract infection, and hemorrhoids, among others. However, use of this class of drugs is associated with the possibility of fetal cardiac abnormalities (Lopes, Francisco, Zugaib, 2010).

One patient reported the use of misoprostol for abortion, which is classified as category $\mathrm{X}$ by the FDA. This drug is a prostaglandin indicated for the treatment of gastric ulcer, banned for sale in the country for consumers, due to its contraindication during pregnancy since it is capable of inducing spontaneous incomplete abortion, with the possibility of causing bleeding and need for curettage (Osório-de-Castro et al., 2004).

In regard to the execution of treatment using prescription drugs during pregnancy, it was found that all users of continuous use drugs, such as immunosuppressants, antiepileptics, and antipsychotics, completed the treatment without interruption during pregnancy. Among users of antihypertensives, only $14.3 \%$ did not follow the complete treatment according to the prescribed posology.

In the case of antimicrobials, results showed that
$40.9 \%$ of patients who used antibacterials for systemic use during pregnancy did not complete the treatment and $30.0 \%$ of woman who used gynecological antiinfectives and antiseptics did not complete the treatment as prescribed. These data are alarming, since it reflects the great number of pregnant women who are not properly executing their treatment with antimicrobials, and who are exposing themselves beyond susceptibility to microbial resistance, to infection exacerbations.

A considerable amount of antibiotics used by study participants were indicated due to urinary tract infections (UTI). The inadequate treatment reveled in the study exposes the women to complications of UTI, such as urinary obstruction, preterm labor, premature amniorrhexis, chorioamnionitis, endometritis, and other complications. This also exposes the fetus to risk, making it more vulnerable to premature birth, secondary infection, and even death (Duarte et al., 2008).

In bivariate analyses related to the consumption of more drugs (above the mean of 4 for the study), associations were not verified to be statistically significant with the independent variables of this study.

The results of bivariate analyses verified a probability approximately two times higher for performing selfmedication in the following categories: adult women (above 19 years old), women with family income lower than one times the minimum wage, and women without obstetric history of abortion. However, these associations are not considered statistically significant (Table V).

The associations regarding self-medication which were statistically significant, described in Table V, demonstrate a greater chance of this practice in women who had fewer prenatal visits (six or less), those who smoked during pregnancy, and women with three or more children.

Another point to be emphasized is the association

TABLE IV - Distribution of drugs used for self-medication during gestation, according to the Anatomical Therapeutic Chemical Classification System (ATC), used by puerperal women interned in HC / UFPE after high-risk pregnancy, 2011

\begin{tabular}{lccl}
\hline Therapeutic classes (ATC code) & $\mathrm{N}$ & $\mathbf{\%}$ & Drugs \\
\hline Analgesics (N02) & 16 & 20.5 & $\begin{array}{l}\text { acetylsalicylic acid, dipyrone, paracetamol } \\
\text { diclofenac sodium, diclofenac potassium, }\end{array}$ \\
Antiinflammatory and antirheumatic products (M01) & 3 & 3.9 & mefenamic acid \\
Vitamins (A11) & 2 & 2.6 & multivitamins, vitamin C \\
Muscle relaxants (M03) & 1 & 1.3 & orphenadrine \\
Antihistamines for systemic use (R06) & 1 & 1.3 & dimenhydrinate \\
Expectorants (R05C) & 1 & 1.3 & carbocisteine \\
Throat preparations (R02) & 2 & 2.6 & benzalkonium \\
Nasal preparations (R01) & 2 & 2.6 & naphazoline \\
Oxytocics (G02A) & 1 & 1.3 & misoprostol \\
\hline
\end{tabular}


between the number of prenatal consultations and selfmedication. In this case, the pregnant women already have an aggravating factor, which is the inadequacy of their obstetric follow-up, and are exposed to the risk of using substances without medical supervision. This doubles their risks.

The association between self-medication and tobacco use is worrying since smoking may increase drug potential

TABLE V - Prevalence of self-medication during gestation by study variables in puerperal women interned in HC / UFPE after high-risk pregnancy, 2011

\begin{tabular}{|c|c|c|c|c|c|}
\hline \multirow{3}{*}{ Variables } & \multicolumn{5}{|c|}{ Use of medicines without prescription (self-medication) } \\
\hline & \multicolumn{2}{|c|}{ No } & \multicolumn{2}{|c|}{ Yes } & \multirow{2}{*}{$\begin{array}{c}\text { OR } \\
(95 \% \mathrm{CI})\end{array}$} \\
\hline & (n) & $(\%)$ & (n) & $(\%)$ & \\
\hline \multicolumn{6}{|l|}{$\overline{\text { Age (years) }}$} \\
\hline 10 to 19 & 13 & 81.25 & 3 & 18.75 & 1 \\
\hline$\geq 20$ & 43 & 69.35 & 19 & 30.65 & $1.92(0.49-7.51)$ \\
\hline \multicolumn{6}{|l|}{ Origin } \\
\hline Countryside & 25 & 73.53 & 9 & 26.47 & 1 \\
\hline Metropolitan region & 31 & 70.45 & 13 & 29.55 & $1.17(0.43-3.17)$ \\
\hline \multicolumn{6}{|l|}{ Race } \\
\hline Caucasian/Asian/Other & 15 & 78.95 & 4 & 21.05 & 1 \\
\hline Black/Brown/Indigenous & 41 & 69.49 & 18 & 30.51 & $1.65(0.48-5.66)$ \\
\hline \multicolumn{6}{|l|}{ Marital Status } \\
\hline With partner & 50 & 71.43 & 20 & 28.57 & 1 \\
\hline Without partner & 6 & 75.00 & 2 & 25.00 & $0.83(0.15-4.48)$ \\
\hline \multicolumn{6}{|l|}{ Number of children } \\
\hline 1 to 2 & 47 & 78.33 & 13 & 21.67 & 1 \\
\hline$\geq 3$ & 9 & 50.00 & 9 & 50.00 & $3.62(1.19-10.96)$ \\
\hline \multicolumn{6}{|c|}{ Educational status (years of study) } \\
\hline$\geq 8$ & 43 & 75.44 & 14 & 24.56 & 1 \\
\hline$<8$ & 13 & 61.90 & 8 & 38.40 & $1.89(0.65-5.50)$ \\
\hline \multicolumn{6}{|l|}{ Family Income } \\
\hline$>1$ minimum wage & 37 & 78.72 & 10 & 21.28 & 1 \\
\hline$\leq 1$ minimum wage & 19 & 61.29 & 12 & 38.71 & $2.34(0.86-6.39)$ \\
\hline \multicolumn{6}{|c|}{ Number of prenatal consultations } \\
\hline$\geq 7$ & 39 & 82.98 & 8 & 17.02 & 1 \\
\hline$<7$ & 17 & 54.84 & 14 & 45.16 & $4.02(1.42-11.34)$ \\
\hline \multicolumn{6}{|l|}{ Gestational age (weeks) } \\
\hline$\leq 37($ preterm $)$ & 17 & 60.71 & 11 & 39.29 & 1 \\
\hline$>37($ term $)$ & 39 & 78.00 & 11 & 22.00 & $0.44(0.16-1.20)$ \\
\hline \multicolumn{6}{|l|}{ Health services } \\
\hline Only SUS & 13 & 72.22 & 5 & 27.78 & 1 \\
\hline SUS and private & 43 & 71.67 & 17 & 28.33 & $1.03(0.32-3.33)$ \\
\hline \multicolumn{6}{|l|}{ Smoked } \\
\hline No & 52 & 76.47 & 16 & 23.53 & 1 \\
\hline Yes & 4 & 40.00 & 6 & 60.00 & $4.88(1.22-19.45)$ \\
\hline \multicolumn{6}{|l|}{ Drank alcohol } \\
\hline No & 47 & 72.31 & 18 & 27.69 & 1 \\
\hline Yes & 9 & 69.23 & 4 & 30.77 & $1.16(0.32-4.25)$ \\
\hline \multicolumn{6}{|l|}{ Previous abortion } \\
\hline Yes & 13 & 81.25 & 3 & 18.75 & 1 \\
\hline No & 43 & 69.35 & 19 & 30.65 & $1.92(0.49-7.51)$ \\
\hline \multicolumn{6}{|c|}{ Know the risk of drug use in pregnancy } \\
\hline Yes & 49 & 71.01 & 20 & 28.99 & 1 \\
\hline No & 7 & 77.78 & 2 & 22.22 & $0.70(0.13-3.66)$ \\
\hline
\end{tabular}


for teratogenesis. This occurs because the cigarette smoke consists of a mixture of numerous inductors and inhibitors of P450 substrates, and thus, is capable of modifying drug clearance or endogenous metabolism (Nakamura, Junior, Pasquale, 2008; Czekaj et al., 2005).

The positive association between self-medication and a greater number of children found in this study corroborates the study of Guerra et al. (2008), where a statistically significant association was verified between self-medication and multiparous women. A reason for this association was not found in medical literature; however, we speculate that multiparous women have a higher tendency for self-medication due to their experience of using medicines during previous pregnancies, and their assumption that medicines will not cause problems in the current pregnancies.

The present study found some limitations to its execution: (1) the possibility of recall bias, due to the need to remember medication used since the beginning of pregnancy, (2) the possibility of omission of questions about self-medication, (3) the inherent particularities of the postpartum period, which, in some cases, have become obstacles to data collection.

\section{CONCLUSIONS}

Considering that the study was performed only with puerperal women with high-risk pregnancies, the average drug consumption did not differ from other works with pregnant women in general. Despite the small number of women unaware of drug use risks during pregnancy, the practice of self-medication still exists, even with access to health care units. Self-medication was related to pregnant women with lower number of antenatal visits and smokers, requiring special attention to this group in order to discourage this habit, not only because of the damage smoking can cause to the fetus, but also because of its potential to increase the teratogenic power of other drugs.

Based on the reported data, vulnerability of this population of women to the risks from the use of drugs is evident, and this is a gap in the field of practice that needs urgent intervention by way of health education. Also in this context, the need of the pharmacist in primary health care units is highlighted, in order to ensure the rational use of medicines during pregnancy, with a consequent reduction of problems due to medicine misuse.

\section{REFERENCES}

BARROS, J.A.C. Propaganda de medicamentos: atentado à saúde? São Paulo: Hucitec, 1995. p.21-74.
BRASIL. Ministério da Saúde. Secretaria de Atenção à Saúde. Departamento de Ações Programaticas Estratégicas. Gestação de alto risco: manual técnico. 5.ed. Brasília: Editora do Ministério da Saúde, 2010. 302 p.

BRASIL. Ministério da Saúde. Secretaria de Atenção à Saúde. Departamento de Ações Programaticas Estratégicas. Área técnica da mulher. Pré-natal e puerpério: atenção qualificada e humanizada - manual técnico. Brasília: Ministério da Saúde, 2005. 158 p.

BRASIL. Ministério da Saúde. Secretaria Executiva. Programa humanização do parto: humanização no pré-natal e nascimento. Brasília: Ministério da Saúde, 2002. 27 p.

BRUM, L.F.S.; PEREIRA, P.; FELICETTI, L.L.; SILVEIRA, R.D. Utilização de medicamentos por gestantes usuárias do Sistema Único de Saúde no município de Santa Rosa (RS, Brasil). Ciênc. Saúde Colet., v.16, n.5, p.2435-2442, 2011.

CARMO, T.A. Medicamentos e gravidez. Saúde Rev., v.5, n.10, p.55-61, 2003.

CAVALLI, R.C.; BARALDI, C.O.; CUNHA, S.P. Transferência placentária de drogas. Artigo de revisão. Rev. Bras. Ginecol. Obstet., v.28, n.9, p.557-564, 2006.

CZEKAJ, P.; WIADERKIEWICZ, A.; FLOREK, E.; WIADERKIEWICZ, R. Tobacco 7. smoke-dependent changes in cytochrome $\mathrm{P} 450$ 1A1, 1A2, and 2E1 protein expressions in fetuses, newborns, pregnant rats, and human placenta. Arch. Toxicol., v.79, n.1, p.13-24, 2005.

DELLA-GIUSTINA, K.; CHOW, G. Medications in pregnancy and lactation. Emerg. Med. Clin. North Am., v.21, n.3, p.585-613, 2003.

DEPARTMENT OF HEALTH AND HUMAN SERVICES. Food and drug administration. Content and format of labeling for human prescription drug and biological products; requirements for pregnancy and lactation labeling: proposed rule. Federal Register, v.73, n.104, 2008. Available at: $<$ http://www.gpo.gov/fdsys/pkg/FR-2008-0529/pdf/E8-11806.pdf >. Accessed on: 31 Jan. 2013.

DUARTE, G., MARCOLIN, A.C., QUINTANA, S.M., CAVALLI, R.C. Infecção urinária na gravidez. Rev. Bras. Ginecol. Obstet., v.30, n.2, p.93-100, 2008. 
FONSECA, M.R.C.C.; FONSECA, E.; BERGSTEN-MENDES, G. Prevalência do uso de medicamentos gravidez: uma abordagem farmacoepidemiológica. Rev. Saúde Pública, v.36, n.2, p.205-212, 2002.

FONTOURA, A. Utilização de medicamentos por gestantes em atendimento pré-natal em uma maternidade no município de Ribeirão Preto - SP. Ribeirão Preto, 2009. 121 p. [Dissertion of máster degree. Pharmaceutical Sciences Graduate Program. School of Pharmaceutical Sciences of Ribeirão Preto, University of São Paulo].

FREIRE, K.; PADILHA, P.C.; SAUNDERS, C. Fatores associados ao uso de álcool e cigarro na gestação. Rev. Bras. Ginecol. Obstet., v.31, n.7, p.335-341, 2009.

GEDEON, C.; BEHRAVAN, J.; KOREN, G.; PIQUETTEMILLER, M. Transport of glyburide by placental ABC transporters: implications in fetal drug exposure. Placenta, v.27, n.11-12, p.1096-1102, 2006.

GEIB, L.T.C.G.; VARGAS-FILHO, E.F.; GEIB, D.; MESQUITA, D.I.; NUNES, M.L. Prevalência e determinantes maternos do consumo de medicamentos na gestação por classe de risco em mães de nascidos vivos. Cad. Saúde Pública, v.23, n.10, p.2351-2362, 2007.

GOMES, R.; CAVALCANTI, L.F.; MARINHO, A.S.N.; SILVA, L.G.P. Os sentidos do risco na gravidez segundo a obstetrícia: um estudo bibliográfico. Rev. Latino-Am. Enferm., v.9, n.4, p.62-67, 2001.

GUERRA, G.C.B.; SILVA, A.Q.B.; FRANÇA, L.B.; ASSUNÇÃO, P.M.C.; CABRAL, R.X.; FERREIRA, A.A.A. Utilização de medicamentos durante a gravidez na cidade de Natal, Rio Grande do Norte, Brasil. Rev. Bras. Ginecol. Obstet., v.30, n.1, p.12-18, 2008.
LOPES, L.M.; FRANCISCO, R.P.V.; ZUGAIB, M. Antiinflamatórios e alterações cardíacas fetais. Editorial. Rev. Bras. Ginecol. Obstet., v.32, n.1, p.1-3, 2010.

MELO, S.C.C.S.; PELLOSO, S.M.; CARVALHO, M.D.B.; OLIVEIRA, N.L.B. Uso de medicamentos por gestantes usuárias do Sistema Único de Saúde. Acta Paul. Enferm., v.22, n.1, p.66-70, 2009.

MENGUE, S.S.; SCHENKEL, E.P.; SCHMIDT, M.I.; DUNCAN, B.B. Fatores associados ao uso de medicamentos durante a gestação em seis cidades brasileiras. Cad. Saúde Pública, v.20, n.6, p.1602-1608, 2004.

MORGAN, D.J. Drug disposition in mother and foetus. Clin. Exp. Pharmacol. P., v.24, n.11, p.869-873, 1997.

NAKAMURA, M.U.; JUNIOR, L.K.; PASQUALE, M. Uso de fármacos na gravidez: benefício e custo. Rev. Bras. Ginecol. Obstet., v.30, n.1, p.1-4, 2008.

OLIVEIRA, A.C.P.; FONSECA, T.M.M. Estudo epidemiológico sobre o uso de medicamentos durante a gravidez na população atendida pelo serviço de obstetrícia do Hospital Municipal de Confresa-MT. Interseção, v.1, n.1, p.102109, 2007.

OSORIO-DE-CASTRO, C.G..S.; PEPE, V.L.E.; LUIZA, V.L.; COSENDEY, M.A.E.; FREITAS, A.M.; MIRANDA, F.F.; BERMUDEZ, J.A.Z.; LEAL, M.C. Uso indicado e uso referido de medicamentos durante a gravidez. Cad. Saúde Pública, v.20, suppl.1, p.73-82, 2004.

Received for publication on $07^{\text {th }}$ June 2012 Accepted for publication on $07^{\text {th }}$ May 2013 